\title{
TLR3 wt Allele
}

National Cancer Institute

\section{Source}

National Cancer Institute. TLR3 wt Allele. NCI Thesaurus. Code C52238.

Human TLR3 wild-type allele is located within $4 q 35$ and is approximately $16 \mathrm{~kb}$ in leng th.

This allele, which encodes toll-like receptor 3 protein, plays a role in host defense ag ainst viruses, pathogen recognition and innate immunity. 